\title{
The informativeness of roof tremor hazard analysis based on seismic measurements and analytical modelling
}

\author{
Dariusz Chlebowski* and Zbigniew Burtan \\ AGH University of Science and Technology, Faculty of Mining and Geoengineering, \\ Kraków, Al. Mickiewicza 30, Poland
}

\begin{abstract}
Rock bursts are a common hazard in Polish hard-coal mines. Their magnitude depends on the state of stress in the mining area, and on underground mining-induced seismicity. Both long-term and ongoing assessments of the capacity of the rock mass to generate tremors are based on geological and mining surveys, rock property measurements (in laboratories and in-situ) and observations involving signs of rock mass pressure, supported by available concepts applicable to geomechanical and geophysical measurements. These include seismic measurements, including profiling, scanning, passive/active geotomography and analytical techniques. This paper presents a comparative analysis involving exemplary results provided by both seismic and analytical methods for a selected panel in one of Upper Silesian Coal Basin (USCB) mines. For the purposes of our seismic measurements, we employed seismic tomography for the geotomographic reconstruction of velocity fields. Subsequently, we compared the results with the results of analytical modelling of rock stresses that relied on classical engineering solutions applicable to problems of mechanics of deformable bodies. The tremor hazard analysis was based on observations of changes in P-wave velocity distributions in the coal seam environment relative to the evolution of the vertical stress concentration factor at the level of a potentially seismogenic roof layer.
\end{abstract}

Keywords: underground mining, rockburst hazard, seismic tomography

\section{Introduction}

Rockburst prevention in hard-coal mines, which includes hazard assessments in specific geological and mining conditions found in the area to be mined, involves a wide use of geophysical methods - in particular seismological and seismoacoustic observations, and seismic measurements, such as rock profiling and scanning. In many cases the types and scopes of preventive measures are selected on the basis of geophysical measurement results. These are additionally supported by analytical or numerical measurements used to determine the range and magnitude of stress concentration zones in the rock mass, and to

\footnotetext{
*Corresponding author: chlebo@agh.edu.pl
} 
delimit the boundaries of destressed areas around the longwall faces and development workings.

In most of today's USCB mines, mining work is constrained by the presence of minedout areas and geological disturbances, among other factors, contributing to high-energy tremors, and thereby increasing the rockburst hazard. From a geomechanical point of view, these constraints lead to stress changes and, consequently, changes in the elastic strain energy density in rock formations. On the one hand, these changes extend to the coal seams below and above, meaning that the seam energy is more likely to cause a rock burst. On the other hand, by affecting the entire rock mass, such factors also impact on potentially seismogenic layers and, by extension, on the seismic hazard associated with their activation due to cracking.

This paper focuses on the latter aspect. It presents a comparative of seismic and rockburst hazard analysis results based on geophysical measurements [1] and an analytical simulation for a exemplary panel in a hard-coal seam (longwall panel \#09a/501) of one of the mines currently operated by the Polska Grupa Górnicza S.A. company. For geophysical measurements we employed seismic tomography for the reconstruction of the P-wave velocity field in the surrounding rocks $[3,5,6,7]$. In the analytical model approach, we employed the classical solutions involving mechanics of deformable bodies $[4,8,9,11]$, as applicable to the evolution of stresses on the seismogenic layer horizon.

\section{Geological and mining conditions in the area under study}

The mining area selected for the purposes of this study was longwall panel \#09a, with a height of 3,6-4,2m, a width of $130 \mathrm{~m}$ and a length of $690 \mathrm{~m}$, located in site B-west of seam 501 at a depth of about $730 \mathrm{~m}$. The coal is worked by the caving method similarly to the longwall method (Fig. 1), with the wall starting from the cross-cut driven in the goaf zone (\#09) and proceeding further along the goafs of another longwall (\#08) to the east, between headings IXa (to the south) and Xb-west (to the north).

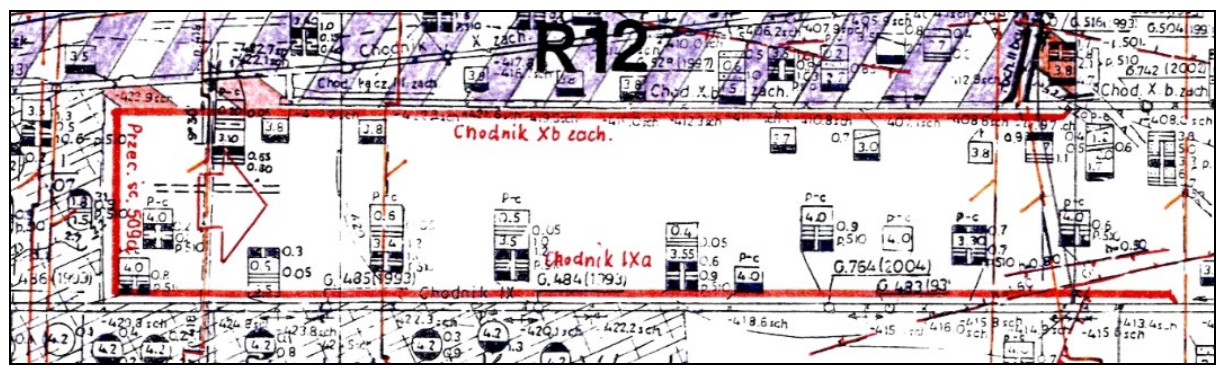

Fig. 1. A map fragment showing seam 501 workings near longwall panel \#09a [10].

Seam 501 in the area under study has a thickness of 3,9-5,3m and a varying dip angle of about $4-6^{\circ}$ in the south-western direction. Directly in the roof, there is a sandstone layer with a thickness of 3,1-7,8m, followed by a layer of argillaceous schist, with occasional inclusions of coal with a thickness of $0,3-0,5 \mathrm{~m}$, and further by a sandstone layer with a thickness of $11,8-14,2 \mathrm{~m}$. The working floor contains deposits of argillaceous schist with a thickness of $0,6-0,9 \mathrm{~m}$, which forms an interlayer between seams 501 and 510, followed by seam 510 with a thickness of 9,8-11,6m. Along the longwall length, there are faults found in the course of mining operations, including in the cross-cut of longwall \#09a, with throws of $0,5 \mathrm{~m}$ and $1,8 \mathrm{~m}$, respectively, and in panel $\mathrm{Xb}$-west, with a throw of $0,3 \mathrm{~m}$. In addition, running through the panel are the mining edges of seams $405,404 / 5$ and 401 , at vertical distances of about 180, 205 and 270m, respectively, and galleries in seam 416/418 at a vertical distance of 50-55m [2]. 
The averaged values of strength parameters determined via penetrometer testing are 12,0-31,2MPa for coal, 19,5-72,0MPa for sandstone, 12,0-33,6MPa for claystone and 16,8$60,0 \mathrm{MPa}$ for the occasional arenaceous shale. We classified seam 501 near the wall panel as involving a 3rd degree rockburst hazard (as per formal regulations applicable at the time) and belonging to the 3rd group of ignitability, the 4th category of methane hazard, and class $\mathrm{B}$ of dust hazard, and involving the 1st and 2nd degrees of water hazard.

\section{Measurement methodology and roof tremor hazard analysis in the light of seismic measurements}

To assess the state of stress and the tremor hazard caused by the activation of roof formations along the length of longwall $\# 09 \mathrm{a} / 501$, we performed measurements using seismic tomography in four measurement series (stages). In series 1, 2 and 3, we performed measurements between heading Xb-west, the wall face and heading IXa. In stage 4 we additionally took measurements for incline 3 (Fig. 1). The scanning covered the forefield of the longwall along a length of about $350 \mathrm{~m}$ from the cross-cut (series 1), along 300 -metre sections ahead of the face from the local position of the mining wall in the next two series (2 and 3), and along a 290-metre panel section in the last measurement series (4). We generated tremors using small explosives detonated in blast holes located every $25 \mathrm{~m}$ in heading IXa, and every $40 \mathrm{~m}$ in the cross-cut. For measurement series 4 , an additional blast hole was made in incline 3, at a distance of about $40 \mathrm{~m}$ from heading $\mathrm{Xb}$-west. The resulting seismic waves were recorded with geophone sondes in the southern sidewall of heading Xb-west. The measurement objective was to obtain technically correct seismograms allowing the determination of seismic wave travel times within the rocks surrounding the seam. The configuration of geophones and excitation points depended on the existing and accessible workings (Fig. 2).
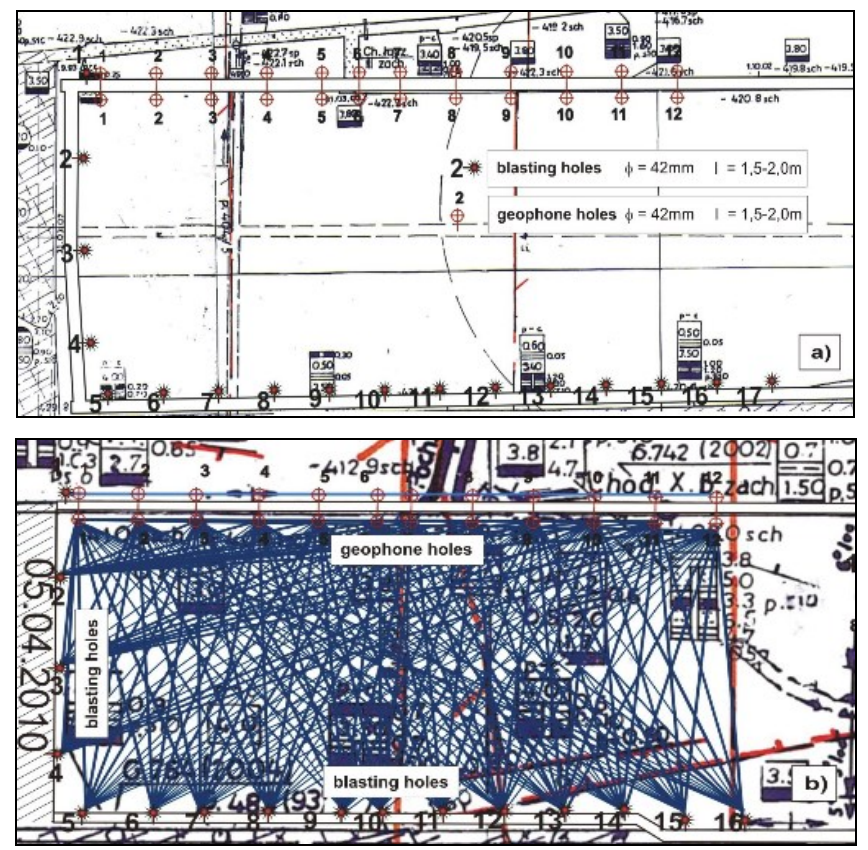

Fig. 2. The testing ground near the area of seismic measurements (a - series $1, b-$ series 3$)$ [1]. 
Vibrations were recorded on the seam plane parallel and perpendicular to the seismic ray. With the recording time of $500 \mathrm{~ms}$ and a seismic ray length of $15 \div 335 \mathrm{~m}$, we could record $\mathrm{P}$ and $\mathrm{S}$ waves surrounding the seam. The seismic sampling interval (1000 samples/channel) was $0,5 \mathrm{~ms}$, thus limiting the recorded frequency to the threshold value of $1000 \mathrm{~Hz}$. Based on the recorded seismograms, following filtration and phase correlation, we determined the first P-wave arrival times in the rocks surrounding the seam (further sequences allow the determination of P-and S-wave arrival times in the seam). Subsequently, we computed the ray velocities of the waves and verified the computation procedure by performing a statistical analysis of ray lengths, times and ray velocities. By analysing the linear correlation and regression between times and distances, we could eliminate systematic errors for individual seismic routes through a constant time correction. This is of significance when recording the first refraction wave arrivals, as the time correction term extends the observation to the boundary between the seam and the rocks surrounding it. An analysis of the time-path linear correlation and regression is useful in exploring seismic wave traverses in terms of the propagation of refracted waves in a continuous or discrete gradient medium. Moreover, it allows the elimination of errors due to the first refracted wave arrival being mistaken for a refraction wave [1]. In the next stage, we reconstructed the velocity fields of individual waves using seismographic tomography with the Simultaneous Iterative Reconstruction Technique (SIRT). That is one of the methods of iterative process and generally includes the following steps: ray tracing, calculation the ray distance (in cells that ray passes through them), calculation the residual time for ray based on slowness distribution, repeat steps for all rays, modification the slowness in each cell with regard to all the passing rays. The surface was decomposed into $20 \times 20 \mathrm{~m}$ size sections and the iterative procedure was repeated until the error involved in reconstruction was effectively reduced to the noise level or levelled off. Accordingly, the measure of the reconstruction error was the standard deviation of the set of differences between the measured and computed times, derived from the reconstructed field of wave velocities along all the seismic rays.

For the purposes of this study and the related comparisons with analytical models, geophysical measurement data were limited to selected parameters of the velocity field of seismic waves only:

- in the rocks surrounding the seam (the distributions in the seam were omitted),

- for two measurement series (1 and 3), considered as example but also of prime interest.

The data are shown as contour maps (zones) of P-wave velocity (Fig. 3).

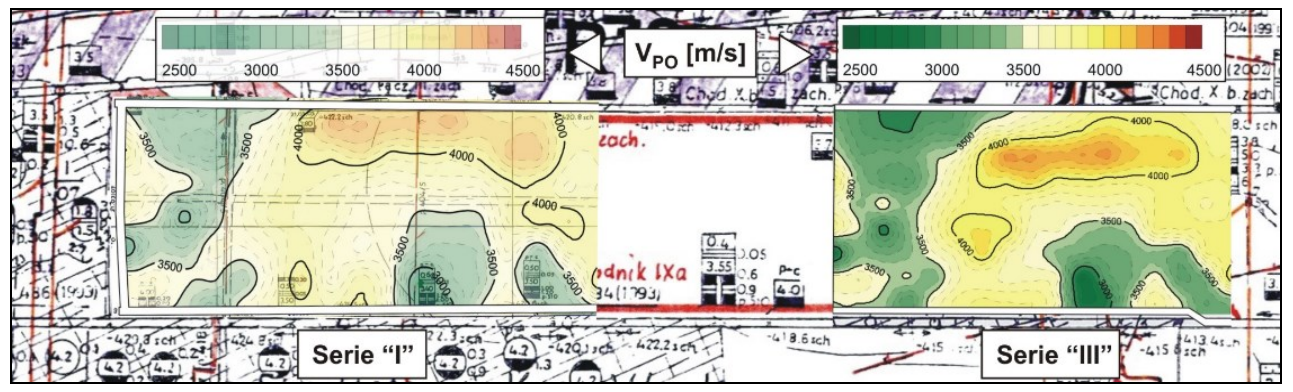

Fig. 3. Distribution of $\mathrm{P}$-wave velocity in the seam roof (longwall panel $\# 09 a / 501)$ [1].

The P-wave velocities in the seam roof across the scanned area varied in the range of $2650-4400 \mathrm{~m} / \mathrm{s}$ for measurement series 1 (Fig. 3), 3100-4500m/s for series 2, 2900-4450m/s for series 3 (Fig. 3) and $2470-4280 \mathrm{~m} / \mathrm{s}$ for series 4 . The reconstructed velocity field reflected variability in P-wave propagation conditions in the seam roof. Despite the velocity field being unimodal, the velocity was highly variable - measurement series 1 showed the big- 
gest velocity variations, while for subsequent series these variations were moderate. The velocity field variability parameter was over $10 \%$ for series 1 and 4 , and over $5 \%$ for series 2 and 3. For all the measurement series, no velocities over $4500 \mathrm{~m} / \mathrm{s}$ were found in the field distribution, while velocities of more than $4000 \mathrm{~m} / \mathrm{s}$ were identified locally (depending on the measurement series) in the northern panel section, ahead of the mining face or near headings IXa and $\mathrm{Xb}$-west [1]. Zones with significantly lower velocities, where roof rocks might be weakened, were found along the 140-200 metre section from the stoppage line in heading IXa (series 1 and 3), the 30-80 metre section from the face in heading Xb-west (series 3), in heading IXa along the 20-60 metre section ahead of the face, and in heading $\mathrm{Xb}$-west along the 25-65 metre section west of the design wall-length end (series 4).

These examples suggest that for all measurement series, the rocks surrounding seam 501 in the observed area exhibited moderate potential for generating roof tremors. This is supported by the average P-wave velocity around the seam - of $3600 \mathrm{~m} / \mathrm{s}$ (for series 1, 2 and 3 ) and $3750 \mathrm{~m} / \mathrm{s}$ (for series 4 ) - found over $67-70 \%$ and $82 \%$ of the scanned area, respectively. Locally, where the velocity dropped below $3500 \mathrm{~m} / \mathrm{s}$, the capacity of roof rocks to generate tremors was weak. These areas accounted for about 30\% (series 1 and 2), 34\% (series 3 ) and $18 \%$ (series 4 ) of the mining site under study. We found no clear correlation between the zones with increased velocity gradients around low-velocity anomalies in the roof and seam, suggesting the potential development of slip tremors [1, 6, 7].

Considering the above, including the fact that the anomalies and increased $\mathrm{P}$-wave velocity areas (vs baseline) around the seam, as found by the seismic measurements, suggest the potential for stress concentration (relative to the lithostatic state), the panel of longwall \#09a/501 under study will involve a seismic hazard - caused by roof formations being activated due to their cracking - that varies between individual phases, but is generally moderate.

\section{Methodological assumptions and the analysis of the potential for seismogenic layers to activate in the light of analytical modelling}

The key factors behind the magnitude of the rockburst hazard include the state of stress in the area of the mining operations, the geomechanical properties of the rock mass and induced seismicity due to the failure of compact, monolithic rock packets (sandstones, arenaceous shales). With regard to the last of these factors, in order for such a tremor to occur, the rock structure must fail due to the critical stress intensity being reached in a specific area of the seismogenic layer $[2,8,10]$. The stress intensity in the rock due to deformation processes can be described by the stress intensity factor, whose value for a Mohr-Coulomb criterion is a function of strength parameters and principal stresses. The stress components in the layer under study are determined by the depth of its deposition and the impacts of mined-out areas and tectonic disruptions. However, they also depend on the mining method and technology, as well as the type and geometry of the workings.

For the assessment of the degree of roof rock deformations at the stage of designing long-term exploitation, especially in areas whose geology is underexplored, it is particularly important to make stress projections (analytical or numerical) relative to the strength parameters of the rock mass. Since these can be used to estimate the magnitude of the rock tremor hazard involved in mining operations, our assessment for longwall panel \#09a was based on the results (in the form of contour maps) of analytical simulations [2], defining the vertical component of the primary stress tensor (Fig. 4) and the concentration factor of these stresses (Fig. 5) on the horizon of the monolithic sandstone layer deposited above seam 501. It should be added that the distributions provided below (Fig. 4, 5) relate to the 
state of mining operations after mining in longwall panel \#08 (in the south) has been completed, and as such do not include the impact of the face of longwall \#09a on seismogenic formations, implying a potential tremor hazard.

The computation procedure showed that the state of stress in the roof above the longwall panel under study (between headings IXa and IXb-west, and the cross-cut and the end line of longwall length) was inhomogenous. This was attributable primarily to the complex of mined-out areas and fault disruptions. Our simulations yielded vertical stress components in the range of 15,9 to $26,6 \mathrm{MPa}$ (Fig. 4) [2]. Hence, they were fragmentarily higher than the uniaxial compression strength of the sandstone under study. This would lead to local critical stress zones, meaning that during the excavation of longwall \#09a, conditions would exist to facilitate the activation (due to the superposition of mining face impacts on the inhomogenous stress state) of seismogenic formations, suggesting a potential tremor hazard (including high-energy tremors).

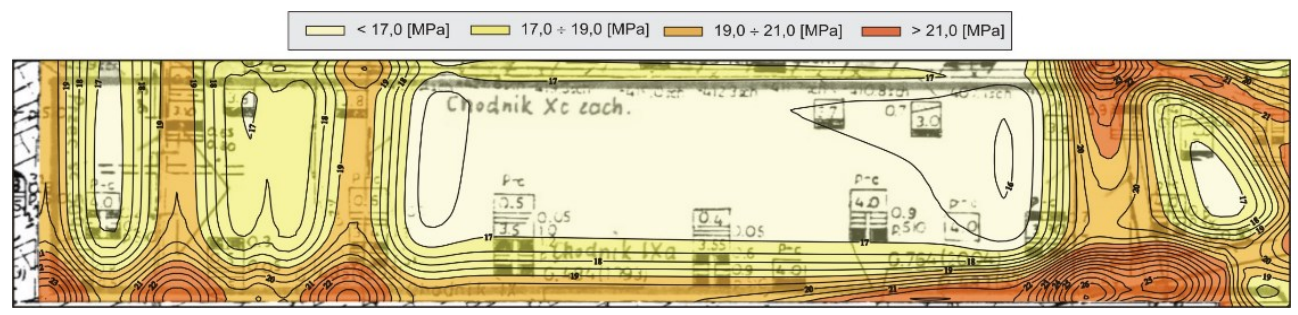

Fig. 4. Map of vertical stresses at the level of the seismogenic layer (longwall panel \#09a/501) [2].

This is supported by the distribution of the concentration factor, described as the quotient of primary and gravitational stresses, its variability being within 0,97-1,60 (Fig. 5) [2]. A stress concentration factor of less than 1 means that the sandstone formations under study feature destressing areas. Most panels, however, were not destressed (concentration factor of more than 1). The distributions in the stress concentration zone could be attributed to the superposition of impacts from goafs of longwalls \#08 (to the south) and \#09 (to the west), faults with throws of up to $1,6 \mathrm{~m}$, and the complex of edges in seams $405,404 / 5$ and 401 . Since the distance between seismogenic formations and mined-out areas in seam 400 is vertical, the impact (during the excavation of longwall \#09a) of the latter on the activation potential of monolithic sandstones should be considered as substantial.

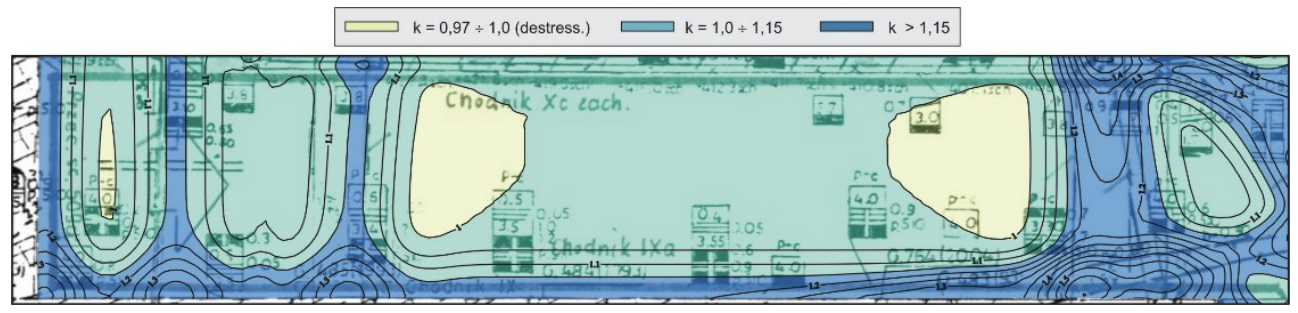

Fig. 5. Map of the vertical stress concentration factor at the level of the seismogenic layer (longwall panel \#09a/501) [2].

The results of analytical modelling can be interpreted in relation to the seismicity projections associated with the development and exploitation works. Given the negligible impact of the face on changes in the state of stress within the rigid and thick seismogenic layers, there is a potential for recording low-energy activity $\left(10^{3}-10^{4} \mathrm{~J}\right)$ when driving galleries due to the failure processes in the seam, or directly in roof rocks. The impact of the longwall face \#09a (at the excavation stage) on the sandstone formations under study will lead to the occasional activation of these formations, causing high-energy tremors. The energies of most events whose sources are located at the seismogenic layer level, due to 
that layer's rigidity, should not exceed $7 \times 10^{5} \mathrm{~J}$, and they are the most likely to occur in the delineated stress concentration zones. In terms of the rockburst hazard, the magnitude of which is the product of the state of stress in the seam (in qualitative terms, it will be similar to that found in the roof) and the projected rock mass seismicity $[8,11]$, it should be assumed that the wall's excavation will involve a moderate (locally high) level of hazard, with headings, including heading IXa, being exposed to the greatest hazard.

\section{The effectiveness of the projection methods used}

The analytical assessment [2] and series 1 of geophysical measurements had been performed before mining operations began on longwall \#09a, and the rock mass was scanned in the subsequent measurement series (2-4) [1] during wall excavation. Hence, in order to estimate the effectiveness of the projections, comprehensive information is needed on the induced seismicity across the entire mining area. Accordingly, we recorded a total of 2566 tremors during the mining, including seven with an energy of $10^{5} \mathrm{~J}$ (up to $5,5 \times 10^{5} \mathrm{~J}$ ), 102 tremors of $10^{4} \mathrm{~J}, 1019$ tremors of $10^{3} \mathrm{~J}$ and 1438 tremors of $10^{2} \mathrm{~J}[10]$. The aggregate energy generated by these tremors was $8,7 \times 10^{6} \mathrm{~J}$. The total extraction level of $511000 \mathrm{Mg}$ translated into a unit energy expenditure of about $17 \mathrm{~J} / \mathrm{Mg}$. Given the corresponding data describing the seismic activity of other walls mined in the area (the panel under study was the last to be mined), we may conclude that the relative seismic hazard associated with the excavation works in panel \#09a was moderate. Some of the low-energy seismicity we recorded was clearly due to the failure processes in the seam. However, our observations generally confirmed the earlier projections of the capacity of roof layers to generate tremors (geophysical measurements) and their maximum energy (analytical simulation).

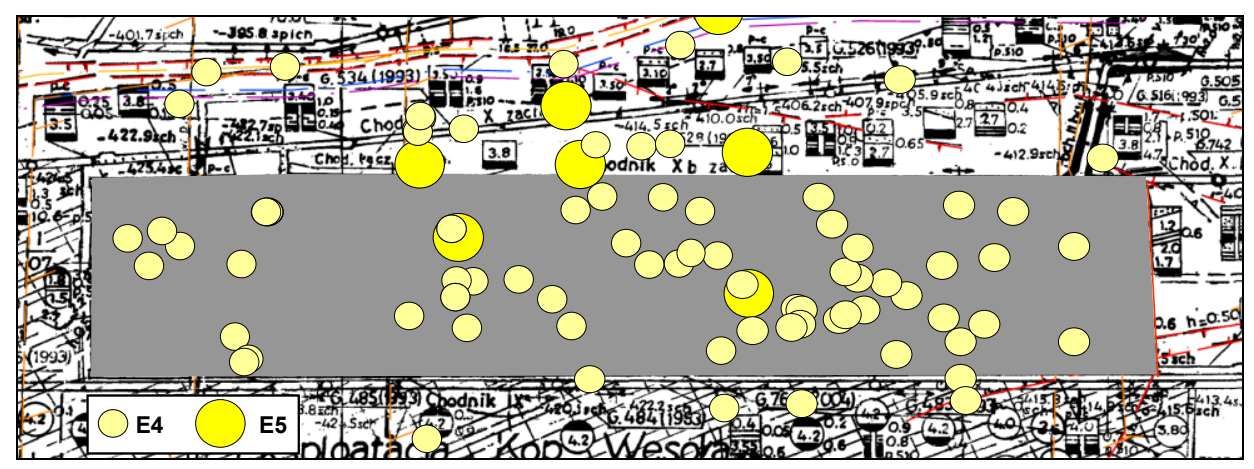

Fig. 6. Location of foci of seismic events (from $1 \times 10^{4} \mathrm{~J}$ ) during the mining (longwall panel \#09a/501 [10]).

With regard to the location of the epicentres of registered seismic events, we may conclude that the distribution of tremors involving seismic energies of more than $1 \times 10^{4} \mathrm{~J}$ (Fig. 6 , location error $\sim 30 \mathrm{~m}$ ) was rather random in nature and poorly correlated with the P-wave velocity zones and/or stress concentration areas in roof rocks we determined in this study. A large majority of the tremors (including high-energy events of $10^{5} \mathrm{~J}$ ) were located outside the area under study - north of the panel envelope and in goafs of neighbouring longwalls, precluding the comprehensive interpretation of the projection results. It is reasonable to assume that such a distribution of tremors was largely attributable to the fault along the northern boundary of the seam section under study, with a throw of 17 to 25 metres, and the parallel mining operations in the seam's hanging longwall. 


\section{Conclusions and summary}

Working from a set of specific geological and mining conditions, this paper provides a synthetic analysis of the evolution of stress states in the seam roof for a selected panel in one of Upper Silesian Coal Basin mines. The study involved the interpretation of the results of seismic rock tomography and analytical simulation. It focused on the seismogenic sandstone layer above longwall \#09a located in the B-west part of the seam, at a depth of about $730 \mathrm{~m}$. The primary aim of our investigations was to compare the results of geophysical measurements with the projections based on solutions applicable to problems of rock mechanics with a view to assessing the tremor hazard due to the failure processes in roof rocks.

This comparative analysis warranted the following general conclusions:

- The methods we used showed that the state of stress in the seismogenic layer was generally inhomogenous. This was due to the presence of mined-out areas in seam group 400, and the nearby location of goafs and faults.

- Analytic projections suggested the presence of local stress concentration zones attributable to the superposition of impacts from goafs and mining edges. However, these impacts were not confirmed by the results of our geophysical measurements.

- In contrast to seismic measurements, the analytical method indicated fragmentary, asymmetrical destressing of the sandstone layer due to the mining operations in seam 405 . However, the effectiveness of this method was assessed as poor.

- The seismic activity in the rock mass recorded during the excavation of longwall $\# 09 \mathrm{a} / 501$ confirmed the projections in regard to the potential of the roof layers to generate tremors, and in respect of the energy of these tremors.

- The projection results proved to be of little use in terms of locating the sources of tremors along the wall length. The distribution of tremors was random in nature and showed poor correlation with the stress concentration zones determined using geophysical and analytical measurement techniques.

Although the results provided by both techniques were not fully consistent, the geophysical and analytical methods presented in this paper could be useful tools to assess the state of the rock mass in terms of the roof tremor hazard involved in hard-coal mining. These methods have been developed consistently to provide increasingly accurate results, helping to make more effective projections [3].

The paper was written as part of the AGH-UST scientific subsidy, No 16.16.100.215

\section{References}

1. Badania geofizyczne dla oceny stanu naprężeń i zagrożenia tapaniami w rejonie projektowanej ściany \#09a w pokładzie 501 w polu B1 - I, II, III, IV seria (Geophysical measurements for the assessment of the state of stress and rockburst hazard in the area of the design longwall \#09a, seam 501, site B1-series 1, 2, 3, 4), Agos-Gemes (2009-2010) (in Polish, unpubl.)

2. Ocena stanu naprężeń i zagrożenia tapaniami oraz wskazanie zasad profilaktyki tapaniowej w polu ściany \#09a w poktadzie 501 pole B1 (Assessment of the state of stress and rockburst hazard, and the identification of rockburst prevention rules in longwall \#09a, seam 501, site B1), Res. Tech. Bur. Geotech II (2008) (in Polish, unpubl.) 
3. P. Bańka, A. Jaworski, Possibility of more precise analytical prediction of rock mass energy changes with the use passive seismic tomography readings, Arch. Min. Sci. 55 (4) (2010)

4. M. Borecki, M. Chudek, Mechanika górotworu (Strata mechanics), Slask Publ. (1972) (in Polish)

5. J. Dubiński, Sejsmiczna metoda wyprzedzajacej oceny zagrożenia wstrzasami górniczymi w kopalniach węgla kamiennego (A seismic method of preemptive rockburst hazard assessment in hard-coal mines), Res. Rep. Centr. Min. Inst. (1989) (in Polish)

6. A. Goszcz, Zapobieganie tapaniom stropowym (Prevention of roof rockbursts), Min. Ener. Econ. Res. Inst. Pol. Acad. Sci. (1993) (in Polish)

7. A. Goszcz, J. Dubiński, J. Dworak, Praktyczne aspekty zastosowania tomografii sejsmicznej $w$ górnictwie podziemnym (Practical aspects of using seismic tomography in underground mining), Res. Rep. Centr. Min. Inst. (1989) (in Polish)

8. Z. Kłeczek, J. Małoszewski, S. Parysiewicz, A Zorychta, Geomechaniczne kryteria zagrożeń tapaniami przy eksploatacji pokładów węgla kamiennego (Geomechanical criteria of rockburst hazards in hard-coal mining), Res. Rep. Centr. Min. Inst. (1987) (in Polish)

9. A. Sałustowicz, Zarys mechaniki górotworu (Fundamentals of strata mechanics), Slask Publ. (1968) (in Polish)

10. J. Wojtynek, J. Szuścik, Z. Kowalczyk, A. Frej, Eksploatacja odprężająca w warunkach koincydencji zagrożeń na przykładzie ścian prowadzonych w pokładzie 501 (Destressing mining in conditions of hazard coincidence as exemplified by seam 501 longwalls), Res. Rep. Centr. Min. Inst., Min. \& Environ. (2010) (in Polish)

11. A. Zorychta, Geomechaniczne modele górotworu tapiacego (Geomechanical models of a bursting rock mass), Min. Ener. Econ. Res. Inst. Pol. Acad. Sci. (2003) (in Polish) 